\title{
Does Money Motivate Employees? Empirical Study of Private and Public Financial Sector in Kazakhstan
}

\author{
Arman Kulchmanov ${ }^{1} \&$ Maniam Kaliannan ${ }^{1}$ \\ ${ }^{1}$ Nottingham University Business School, The University of Nottingham Malaysia Campus, Jalan Broga, \\ Semenyih, Malaysia \\ Correspondence: Arman Kulchmanov, Nottingham University Business School, The University of Nottingham \\ Malaysia Campus, Jalan Broga, Semenyih, Malaysia. E-mail: ksax3aka@nottingam.edu.my
}

Received: August 21, 2014

Accepted: September 18, 2014

Online Published: October 22, 2014

doi:10.5539/ijbm.v9n11p214

URL: http://dx.doi.org/10.5539/ijbm.v9n11p214

\begin{abstract}
Purpose: The paper analyzes the financial and non-financial factors impacting employees' performance of different financial institutes currently operating in Kazakhstan.

Methodology: The survey was conducted by using questionnaire with five-point Likert scale for assessing given statements regarding financial and non-financial motivators at the different organizational and demographic levels for employees at the chosen financial institutes. Additionally was considered different perception of motivational factors within different demographic categories.

Findings: This study proved sustainability Maslow theory of motivation and Herzberg's motivation and hygiene factors at the workplace. Money still is the strongest and compulsory factor for employees, which can satisfy only basic needs. But in isolation of other non-financial motivational factors money are not able to encourage staff to do go beyond their duties and increase their productivity. Job security, internal relationship and transparency were defined by interviewees as the most important non-financial motivation factors. Also there is an advantage of Corporation " $\mathrm{B}$ " which is Government public financial company over private bank - which is bank " $A$ " is higher level of satisfaction of its employees with financial motivation.
\end{abstract}

Research limitations: The study was limited by only two financial institutes study, meanwhile in Kazakhstan there are 42 commercial banks.

Practical implications: The paper analyzes the financial and non-financial factors impacting employees' performance of different financial institutes currently operating in Kazakhstan. The results can be used as a valuable feedback for improvement Strategic HR Policies in considered financial institutes and will be useful for those who are interested in HR Management in Kazakhstan in general.

Keywords: HRM, Kazakhstan, motivation, financial factors, non-financial factors, Maslow, Herzberg

\section{Introduction}

Is money the main motivation for employees to perform well? What are the main forces influencing workers to do their best in a job? Answers to these questions are the key sources for employers to maintain workplace in order to achieve the highest results with happy staff. On the other hand, ignorance of motivation seeking and employees' needs satisfaction is the threat for a firm to lose their market position with high extra cost - expenses for retaining, training programs and opportunity cost, represented by losing key staff and absenteeism in the workplace. Defining motivation of employees is proactive action which should be conducted by HR managers as a strategic approach and it is a naïve to rely on the money as the main catalyst of the performance. Nohria (2008) argues that motivational factors are crucial to handle correctly in the goal to become a successful organization. Hence, what is the motivation, what factors are coming with money as a motivation and does good package alone able to satisfy employees' needs are questions, which this paper is attempting to answer. 


\section{Literature Review}

Maslow (1943) was the one of the most successful psychologist who managed to explain human needs, and determine motivational drives by dividing them on five hierarchical levels; each of them is preceding the next one. The "Maslow's needs Pyramid" (see figure 1) levels are: (1) Physiological needs (air, food and water, sex etc.), (2) Safety and security needs (protection, freedom from physical and psychological threat), (3) Social needs (love, feel of belonging and social suitability), (4) Esteem needs (social status, desire for reputation, recognition etc.) and (5) Self-actualization (fully self-realized need. Become what you are capable to becoming).

In this pyramid the basic principle is moving to the next, higher level of need only after previous, lower needs are satisfied. At the same time this hierarchy's first three (physiological, safety and social) needs could be defined as basic without satisfaction which people are not looking for esteem and self actualization needs.

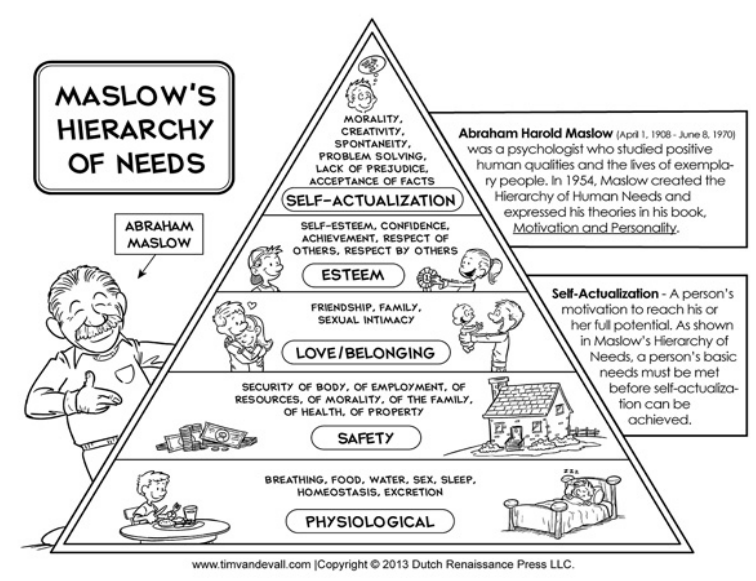

Figure 1. Maslow's needs hierarchy pyramid

Herzberg (1959) came up with the theory of two factors - extrinsic and intrinsic, that affecting the productivity of employees as a result of their job satisfaction (see figure 2). The extrinsic factors - or also known as a hygiene factors-are those, which deal with job context, and thus lead to job dissatisfaction if they are not met. The salary package, job security, working conditions, interrelationship, status of an employee, supervision and firm's rules, procedures and regulation are referred to these factors. However, this is minimal requirements of employee's motivation. Indeed, when extrinsic (or hygienic) factors are considered acceptable or even if they are good, it is not necessary making employee satisfied-it is simply makes him "not dissatisfied". At this level of satisfaction employee is not happy enough to put extra efforts to exceed his basic, acceptable norm of productivity. Second factors group is intrinsic, or motivation factors, which deal with job content and lead to job satisfaction. Recognition, advancement, achievement, responsibility, work itself and growth opportunity are represented these factors. When these factors are not exist in work place employees are not dissatisfied, but they are tend to be "not satisfied", and as a result less motivated to be more productive. But when a firm provide these factors, employee become satisfied, and encouraged (or motivated) to put extra efforts with increased productivity as a result of fulfilling personal psychological needs of self developing. 


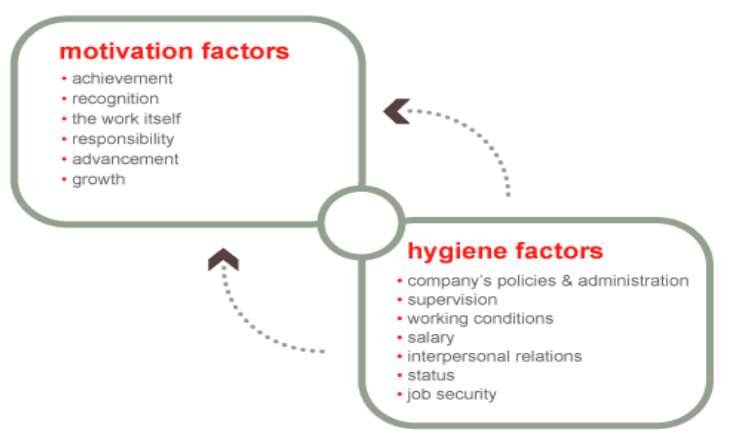

Figure2. Herzberg's motivation-hygiene factors

Apart from conventional theories of staff motivation the huge number of empirical study about role of money and financial incentives as the main motivators, strength of the linkage between money and employee motivation and what non-financial motivators could compete with money were conducted. Judge and his colleagues synthesized 92 quantitative studies (by reviewing 120 years timeline) in their large meta-study, and found that job satisfaction is lowly related to the salary. Gallup's engagement research (2010) conducted among 1.4 million employees from 192 companies across 49 industries and 34 nations showed that there is no significant relationship between employee engagement and level of payment. Deci and colleagues (1999) in their experiments concluded constant negative effects of financial incentives on intrinsic motivation. And this effect has been increasing with tasks are interesting and enjoyable rather than uninteresting and pointless. However, Cameron and colleagues (1994) in their meta-analysis found that for boring and uninteresting job extrinsic motivation represented by financial incentives increases employee motivation. And in the most recently study of Jik Cho and Perry (2011) among 200 thousand employees in public sector of US was found that intrinsic motives are three times stronger than extrinsic, but both factors are interrelated and cannot exist separately. Hence, employees who were motivated by non-financial factors were three times more engaged comparatively to those whose main motivation factor was money. Or simply saying, an employee is feeling more satisfied when he is focusing on the work itself rather than focusing on the money.

\section{Methodology}

For understanding motivational drivers among employees empirical study was conducted. Analysis was based on a questionnaire (see appendix 1), which contains three sections (section A-demographic characteristics, section B - current satisfaction with financial factors and section C - what are non-financial factors have been considering as motivators). Respondents were asked to give their opinions about both financial and non-financial motivation statement on a five-point Likert scale. Two organizations were studied with comparatively analysis: Bank "A" (see detailed information in appendix 2) and Corporation "B" (see detailed information in appendix 3). These are two huge local Kazakhstan financial institutes, which operate in Kazakhstan. Bank " $A$ " is the private company, but Corporation " $\mathrm{B}$ " is the public company which $100 \%$ belonging to the Government of Republic of Kazakhstan. The data for this study were obtained from questionnaire completed by 27 employees of Bank "A" ( 7 male and 20 female) and 30 employees ( 6 male and 24 female) in Corporation "B". Table 1 shows the detailed subgroups studied in this survey: 
Table 1. Statistics for the survey

\begin{tabular}{|c|c|}
\hline Bank “A” Private Bank (27 employees) & Corporation "B" Public Financial Institute (30 employees) \\
\hline Sex & Sex \\
\hline Male $=7$ & Male $=6$ \\
\hline Female $=20$ & Female $=24$ \\
\hline Age & Age \\
\hline Under $30=14$ & Under $30=7$ \\
\hline $31-40=12$ & $31-40=14$ \\
\hline $41-50=1$ & $41-50=6$ \\
\hline Over $50=0$ & Over $50=3$ \\
\hline Marital status & Marital status \\
\hline Single $=9$ & Single $=11$ \\
\hline Married $=14$ & Married $=16$ \\
\hline Other $=4$ & Other $=3$ \\
\hline Educational achievement & Educational achievement \\
\hline MS's $=0$ & MS's $=1$ \\
\hline Undergraduate $=26$ & Undergraduate $=29$ \\
\hline Others $=1$ & Others $=0$ \\
\hline Organizational level & Organizational level \\
\hline Top management $=1$ & Top management $=1$ \\
\hline Middle management $=12$ & Middle management $=9$ \\
\hline Lower management $=14$ & Lower management $=20$ \\
\hline Working experience in this Organization & Working experience in this Organization \\
\hline Less than 1 year $=5$ & Less than 1 year $=5$ \\
\hline $1-2$ years $=7$ & $1-2$ years $=6$ \\
\hline $3-5$ years $=5$ & $3-5$ years $=6$ \\
\hline More than 5 years $=10$ & More than 5 years $=13$ \\
\hline Income Level (USD/month) & Income Level (USD/month) \\
\hline Less than $1000=12$ & Less than $1000=12$ \\
\hline $1001-2000=13$ & $1001-2000=12$ \\
\hline $2001-3000=2$ & $2001-3000=6$ \\
\hline
\end{tabular}

\section{Results}

\subsection{Financial Factors Analysis}

Survey showed that money attitude of employees in two organizations is completely different. Corporation "B" employees lowest perception about their paying packages were close to be neutral and with tendency to be agreed with other statements (lowest point according to Likert scale is 2.97 for statement that company's benefits packages are better than competitor's and highest was 3.77 for statement that salary is providing high motivation for staff in the company). At the same time Bank "A" employees highest point was 3.26 (statement about company's competitiveness of salary structure) which is neutral perception with tendency to be disagree with other statements. Detailed mean statement assessment represented in table 2: 
Table 2. Employee's perception about financial factors in their company

\begin{tabular}{lllll}
\hline Statement & \multicolumn{2}{l}{ Bank “A” } & \multicolumn{2}{c}{ Corporation "B” } \\
& Mean & Std. Deviation & Mean & Std. Deviation \\
\hline I am very well paid in my Organization & 2.4074 & .84340 & 3.2333 & .9353 \\
In my Organization I am paid based on my KSA & 2.4444 & .9740 & 3.4667 & .9732 \\
(knowledge, skills, abilities) & & & & \\
My Organization's salary structure is very competitive & 3.2593 & .9443 & 3.4000 & .6747 \\
Salary provides high motivation for employees in my Organization & 2.6667 & 1.0742 & 3.7667 & .8976 \\
High salary attracts new employees to my Organization & 3.0000 & 1.0378 & 3.7000 & .7944 \\
Employees in my Organization are paid more salary & 2.2222 & .8473 & 3.2667 & .8683 \\
if they perform better & & & & \\
My Organization provides good benefits package & 2.1111 & .9337 & 3.2333 & 1.0400 \\
for employees & & & & \\
The benefits package offered by my Organization & 2.0370 & .9398 & 2.9667 & .9643 \\
is better than competitor's & & & & \\
\hline
\end{tabular}

By dividing those factors in hierarchy order, table 3 provides information about level of agreeing with statement of financial factors satisfaction level in different organizations. So, there are no statements about financial factors with which Bank "A" employees are agreed. On the other hand Corporation "B" employees are tend to strongly agree with statements that salary in their organization is providing good motivation and attract new employees to their company. Bank "A" employees are completely neutral to agree with statement that high salary attracts new employees to their organization. Also Corporation "B" staff assesses their payment fair regarding to their knowledge, skills and abilities. Both organizations employees are neutral with tendency to agree with statement that organization's salary structure is very competitive. Corporation " $\mathrm{B}$ " staff is moderately agree (neutral with tendency to agree) with statements that their organization pays according to performance, staff is very well paying in their organization with good benefit packages, and also with statement that benefits packages offered by their organization is better than competitor's. For most of these statements with which Corporation "B" employees tend to agree Bank "A" employees showed their negative agreeing level - from neutral with tendency to disagree. It should be highlighted that no statements of financial factors motivating staff was found with which Corporation "B" employees were disagree.

Table 3. Hierarchy of agreeing with financial factors statements' between Bank " $A$ " and Corporation "B"

\begin{tabular}{|c|c|c|}
\hline $\begin{array}{l}\text { Level of agreeing with } \\
\text { statement }\end{array}$ & Bank “A" & Corporation "B" \\
\hline Highest agreeing: & & 1) Salary provides high motivation for \\
\hline Agree with tendency to strongly & & employees in my Organization (3.7667) \\
\hline $\begin{array}{l}\text { agree with statement } \\
\text { (mean } 3.5 \text { and above) }\end{array}$ & No statement & $\begin{array}{l}\text { 2) High salary attracts new employees to my } \\
\text { Organization (3.7000) }\end{array}$ \\
\hline & & $\begin{array}{l}\text { 3) In my Organization I am paid based on my } \\
\text { KSA (knowledge, skills, abilities) (3.4667) }\end{array}$ \\
\hline \multirow{6}{*}{$\begin{array}{l}\text { Moderate agreeing: } \\
\text { Perception of statement is above } \\
\text { neutral with tendency to agree } \\
\text { (mean } 3.0-3.5 \text { ) }\end{array}$} & $\begin{array}{l}\text { 1) My Organization's salary structure is very } \\
\text { competitive ( } 3.2593)\end{array}$ & $\begin{array}{l}\text { 1) My Organization's salary structure is very } \\
\text { competitive }(3.4000)\end{array}$ \\
\hline & $\begin{array}{l}\text { 2) High salary attracts new employees to my } \\
\text { Organization (3.0000) }\end{array}$ & $\begin{array}{l}\text { 2) Employees in my Organization are paid } \\
\text { more salary if they perform better }(3.2667)\end{array}$ \\
\hline & & $\begin{array}{l}\text { 3) I am very well paid in my Organization } \\
(3.2333)\end{array}$ \\
\hline & & $\begin{array}{l}\text { 4) My Organization provides good benefits } \\
\text { package for employees }(3.2333)\end{array}$ \\
\hline & & 5) The benefits package offered by my \\
\hline & & Organization is better than competitor's (2.9667) \\
\hline Disagreeing & Salary provides high motivation & \\
\hline
\end{tabular}




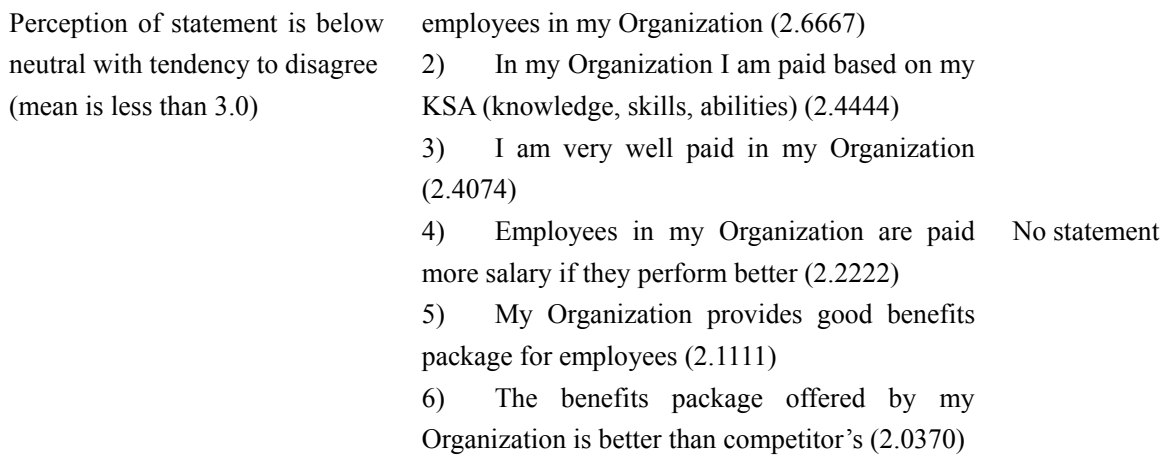

\subsection{Non-Financial Factors Analysis}

Section $\mathrm{C}$ of questionnaire provided data for analysis of other, apart from money, motivation factors importance. The result of analysis is represented in table 4. According to this study the first two the most important job reward factors for both organizations are same - Job security and Interesting job respectively. However third factor by importance of non-financial motivation was personal loyalty to employees for Bank "A" employees (which is the fifth by importance for Corporation "B" employees) and feeling of "being in on things" for Corporation "B" staff (which is the fifth for Bank "A" staff by relevance). Non-financial reward factors such as Promotion and growth in organization and sympathetic with personal problems were considered by both organization's staff as the last by relevance within all list of factors (factors relevance are numbers from 6 to 8 ) with difference in mean amount - so Bank "A" staff tend to be more neutral about importance of growth and sympathetic help with personal problems (with mean 3.2 and 3.2) opposite to Corporation "B", where employees tend to agree about importance of mentioned factors (with mean 3.6 and 3.7 respectively). And there is the big difference between two companies in perception of relevance of full appreciation of work done and good working conditions. So, Bank "A" employees are neutral about relevance of full appreciation of work done and see that as the last important in the list (mean 3.1). At the same time Corporation "B" staff are strongly agree that this factor as the one of the important in the list (fourth position with mean 3.9). At the same time good working conditions for Corporation "B" employees is the last important in the list (position 7) at the time in the Bank "A" employees view this is the fourth factor out of eight.

Table 4. Employees perception about importance of non-financial motivators

\begin{tabular}{lllll}
\hline Non financial motivators & Bank "A” & \multicolumn{2}{c}{ Corporation "B” } \\
& Mean & Std. Deviation & Mean & Std. Deviation \\
\hline Interesting job & 3.5556 & .0500 & 4.0333 & .8087 \\
Full appreciation of work done & 3.1111 & .9337 & 3.8000 & .7144 \\
Feeling of being in on things & 3.2963 & .0309 & 3.8667 & .6815 \\
Job security & 3.9630 & .5175 & 4.2333 & .6261 \\
Promotion and growth in Organization & 3.2222 & 1.0500 & 3.5667 & .7739 \\
Good working conditions & 3.3333 & .9608 & 3.6333 & .8899 \\
Personal loyalty to employees & 3.4444 & 1.0127 & 3.7667 & .8172 \\
Sympathetic help with personal problems & 3.2222 & 1.0500 & 3.7333 & .8683 \\
\hline
\end{tabular}

\section{Discussion}

Taking theoretical and conducted empirical studies into account:

4.1 Bank " $A$ "

Applying to Herzberg theory there was found the shortage of extrinsic (hygiene) factors represented by dissatisfied level of financial motivation within the company, staff's need of job security and personal loyalty to employees as the non-financial factors. With these levels of employees' needs satisfaction in organization staff 
tend to be dissatisfied. And according to Maslow's theory listed factors are basic needs, without satisfaction which people are not looking for esteem and self-actualization. Maslow's statement about hierarchical needs satisfaction was proven by given responses about priority in non-financial motivation, where factors such as full appreciation of work done, sympathetic help with personal problems and growth opportunity (esteem needs according to Maslow's hierarchy or recognition and growth opportunity as intrinsic/motivation Herzberg's factors) were considered as the last important. Analysis within demographic groups (see table 5) gives detailed information about:

\subsubsection{Job Security (Non-Financial Motivation Factor Number One)}

There is difference in perception of importance of this factor among gender, organizational level staff and employees' working experience in this organization. So, women see job security as a priority number one at the time men think that it is less important than interesting job and vice-versa (1st and 2nd factors in gender ranking). Top management sees job security as factor number 3 (with paying more attention to personal loyalty to employees and sympathetic help with personal problems). And those who are working less than one year have same perception as men - by giving job security 2 nd position and valuing more interesting job as a motivation.

\subsubsection{Interesting Job (Non-Financial Motivation Factor Number Two)}

Married people see this factor only 3rd (after job security and personal loyalty to employees), top-management evaluated this factor only as 4th and those who are working in this organization more than 1 but less than 5 years ranked this factor as 5 th.

\subsubsection{Personal Loyalty to Employees (Non-Financial Motivation Factor Number Three)}

This factor is the most important non-financial motivator for top management (1st in ranking), and the last important factor for motivation for lower management with similar characteristics - working experience 1-2 years with income level less than 1.000 USD per month.

Table 5. Ranking of non-financial factors within demographic groups in bank "A"

\begin{tabular}{|c|c|c|c|c|c|c|c|c|c|c|c|c|c|c|c|c|c|c|c|c|}
\hline \multirow{2}{*}{$\begin{array}{l}\text { Non-financial } \\
\text { motivation } \\
\text { factors }\end{array}$} & \multicolumn{2}{|c|}{ Sex } & \multicolumn{3}{|c|}{ Age } & \multicolumn{3}{|c|}{ Marital status } & \multicolumn{2}{|c|}{ Educational achievement } & \multicolumn{3}{|c|}{ Organizationallevel } & \multicolumn{4}{|c|}{ Working experience in organization } & \multicolumn{3}{|c|}{ Income level in USD per month } \\
\hline & Male & Female & $\begin{array}{l}\text { Under } \\
30\end{array}$ & $31-40$ & $41-50$ & Single & Married & Other & Undergraduate & Other & $\begin{array}{l}\text { Top } \\
\text { management }\end{array}$ & $\begin{array}{l}\text { Middle } \\
\text { management }\end{array}$ & $\begin{array}{l}\text { Lower } \\
\text { management }\end{array}$ & $\begin{array}{l}\text { Less } \\
\text { than } \\
1 \\
\text { year }\end{array}$ & $\begin{array}{l}1-2 \\
\text { years }\end{array}$ & $\begin{array}{l}3-5 \\
\text { years }\end{array}$ & $\begin{array}{l}\text { More } \\
\text { than } \\
5 \\
\text { years } \\
\end{array}$ & $0-1000$ & $1001-2000$ & $2001-3000$ \\
\hline $\begin{array}{l}\text { Number of } \\
\text { respondents }\end{array}$ & 7 & 20 & 14 & 12 & 1 & 9 & 14 & 4 & 26 & 1 & 1 & 12 & 14 & 5 & 7 & 5 & 10 & 12 & 13 & 2 \\
\hline $\begin{array}{l}\text { Interesting } \\
\text { job }\end{array}$ & 1 & 2 & 2 & 2 & 2 & 2 & 3 & 2 & 2 & 1 & 4 & 3 & 2 & 1 & 5 & 5 & 3 & 2 & 3 & 3 \\
\hline $\begin{array}{l}\text { Full } \\
\text { appreciation } \\
\text { of work done }\end{array}$ & 6 & 8 & 8 & 8 & 7 & 8 & 7 & 7 & 8 & 2 & 5 & 8 & 6 & 8 & 7 & 8 & 5 & 6 & 8 & 5 \\
\hline $\begin{array}{l}\text { Feeling of } \\
\text { being in on } \\
\text { things }\end{array}$ & 4 & 5 & 7 & 4 & 4 & 6 & 6 & 4 & 5 & 4 & 7 & 4 & 5 & 6 & 4 & 6 & 4 & 4 & 5 & 7 \\
\hline Job security & 2 & 1 & 1 & 1 & 1 & 1 & 1 & 1 & 1 & 1 & 3 & 1 & 1 & 2 & 1 & 1 & 1 & 1 & 1 & 1 \\
\hline $\begin{array}{l}\text { Promotion } \\
\text { and growth in } \\
\text { Organization }\end{array}$ & 8 & 6 & 4 & 7 & 6 & 4 & 8 & 6 & 6 & 5 & 8 & 7 & 4 & 5 & 2 & 2 & 8 & 3 & 7 & 8 \\
\hline $\begin{array}{l}\text { Good } \\
\text { working } \\
\text { conditions }\end{array}$ & 7 & 4 & 3 & 6 & 5 & 3 & 5 & 5 & 4 & 3 & 6 & 5 & 3 & 7 & 3 & 3 & 6 & 5 & 4 & 6 \\
\hline $\begin{array}{l}\text { Personal } \\
\text { loyalty to } \\
\text { employees }\end{array}$ & 3 & 3 & 5 & 3 & 3 & 5 & 2 & 3 & 3 & 2 & 1 & 2 & 7 & 3 & 8 & 4 & 2 & 7 & 2 & 2 \\
\hline $\begin{array}{l}\text { Sympathetic } \\
\text { help with } \\
\text { personal } \\
\text { problems }\end{array}$ & 5 & 7 & 6 & 5 & 8 & 7 & 4 & 8 & 7 & 6 & 2 & 6 & 8 & 4 & 6 & 1 & 5 & 8 & 6 & 4 \\
\hline
\end{tabular}




\subsection{Corporation " $B$ "}

Extrinsic (hygiene) factors in this organization represented by good level of employees' satisfaction with financial factors (3 statements out of 8 about financial motivation in the company were strongly agreed, 5 statements moderately agreed and no statements about financial factors disagreeing were found). Same as Bank "A" survey results job security and interesting job are main non-financial motivation factors. However staff recognized shortage of feeling of "being in on the things", or lack of transparency within the organization. Hence, with this kind of barrier Company is incompletely supply to employees' information or could have some kind of deficiencies in internal policies and administration or supervision. If this issue will not be managed by management it could lead to dissatisfaction nevertheless good salary packages are provided. Comparatively to Bank "A" employees' level of satisfaction of extrinsic (hygiene) factors Corporation "B" employees' has got more satisfaction with financial needs. However, factors such as growth opportunity, good working conditions and sympathetic help with personal problems were considered as the last important. Hence we can conclude that money can resolve issues with bad working conditions by simple compensation for some kind of inconvenience, but they cannot motivate people to desiring growth and promotion (esteem needs according to Maslow's hierarchy) or to be more sensitive in work place to help with personal problems (social needs). And here is proving of both Maslow's needs hierarchy and Herzberg's two factors theories - as long as basic needs are not satisfied employees are not aiming to achieve highest level of needs and the level of employees' job satisfaction in these conditions will be "not satisfied", but "not dissatisfied". Analysis within demographic groups (see table 6) defined differences in perception for:

\subsubsection{Job Security (Non-Financial Motivation Factor Number One)}

There is difference in perception of importance of this factor among gender, organizational level staff and employees' working experience in this organization. Men see this factor as 4th by priority. Middle management, workers who have been working 3-5 years and those whose income level 2001-3000 USD per month assess this factor as 2 nd. For all mentioned group interesting job is non-financial motivation factor number one.

\subsubsection{Interesting Job (Non-Financial Motivation Factor Number Two)}

Employees with working experience less than 2 years and income level 0-1000 USD per month are considering this factor as a $3 \mathrm{rd}$ - 4th in their ranking priority. For those people job security and feeling of "being in on things" seem to be more relevant.

\subsubsection{Feeling of Being in On Things (Non-Financial Motivation Factor Number Three)}

For male workers this factor is the less important one (8th position in the ranking), middle management also considering this factor as less relevant one (7th position), but after interesting job and job security (1st and 2nd factors in their non-financial motivation) this group is demanded in sympathetic help with personal problems. Employees with income level 2001-3000 USD per month have got similar characteristics as middle management.

\section{Conclusion}

Maslow's hierarchy of needs and Herzberg's two factors theory proved their validity in the case of Bank "A" and Corporation "B". The money is still be very strong motivation for employees, but their role is only satisfy extrinsic or basic needs, and they could not provide motivation for employees' to achieve higher level of their needs, which means that money is not seem to be factor for motivate employees' to do their best and increase their productivity. Two main points were found among these companies: Bank "A" is required to review their paying policy which is serious threat in staff retaining task. However it is not enough - job security, internal relationship still are serious challenges for working environment there. Corporation "B" paying policy is considered to be relatively good, but job-security and transparency are main factors which prevent staff to be more motivated for their job. Interesting job is the most important non-financial factor which motivates employees'. However it is too complicated to provide interesting job for everybody, but companies still have another mentioned above issues which demotivate employees. By taking these tasks into HR Strategy's agenda companies could improve their motivational factors. Also this study provided detailed information about specific motivational differences among different employees' diversified by gender, organizational level and working experience which could e considered in tactical HR decisions 
Table 6. Ranking of non-financial factors within demographic groups in corporation "B"

\begin{tabular}{|c|c|c|c|c|c|c|c|c|c|c|c|c|c|c|c|c|c|c|c|c|}
\hline \multirow[b]{2}{*}{$\begin{array}{l}\text { Non-financial } \\
\text { motivation } \\
\text { factors }\end{array}$} & \multicolumn{2}{|l|}{ Sex } & \multicolumn{3}{|l|}{ Age } & \multicolumn{3}{|c|}{ Marital status } & \multicolumn{2}{|l|}{ Educational } & \multicolumn{3}{|c|}{ Organizationallevel } & \multicolumn{4}{|c|}{ Working experience in organization } & \multicolumn{3}{|c|}{ Income level in USD per month } \\
\hline & Male & $\begin{array}{l}\text { Femal } \\
\text { e }\end{array}$ & $\begin{array}{l}\text { Under } \\
30\end{array}$ & $31-40$ & $41-50$ & $\begin{array}{l}\text { Singl } \\
\mathrm{e}\end{array}$ & $\begin{array}{l}\text { Marrie } \\
\text { d }\end{array}$ & Other & $\begin{array}{l}\text { Undergradua } \\
\text { te }\end{array}$ & Other & $\begin{array}{l}\text { Top } \\
\text { manageme } \\
\text { nt }\end{array}$ & $\begin{array}{l}\text { Middle } \\
\text { manageme } \\
\mathrm{nt}\end{array}$ & $\begin{array}{l}\text { Lower } \\
\text { manageme } \\
\text { nt }\end{array}$ & $\begin{array}{l}\text { Less } \\
\text { than } \\
1 \\
\text { year }\end{array}$ & $\begin{array}{l}1-2 \\
\text { years }\end{array}$ & $\begin{array}{l}3-5 \\
\text { years }\end{array}$ & $\begin{array}{l}\text { More } \\
\text { than } \\
5 \\
\text { years }\end{array}$ & $0-1000$ & $1001-2000$ & $2001-3000$ \\
\hline $\begin{array}{l}\text { Number of } \\
\text { respondents }\end{array}$ & 7 & 20 & 14 & 12 & 1 & 9 & 14 & 4 & 26 & 1 & 1 & 12 & 14 & 5 & 7 & 5 & 10 & 12 & 13 & 2 \\
\hline Interesting job & 1 & 2 & 2 & 2 & 2 & 2 & 3 & 2 & 2 & 1 & 4 & 3 & 2 & 1 & 5 & 5 & 3 & 2 & 3 & 3 \\
\hline $\begin{array}{l}\text { Full } \\
\text { appreciation of } \\
\text { work done }\end{array}$ & 6 & 8 & 8 & 8 & 7 & 8 & 7 & 7 & 8 & 2 & 5 & 8 & 6 & 8 & 7 & 8 & 5 & 6 & 8 & 5 \\
\hline $\begin{array}{l}\text { Feeling of being } \\
\text { in on things }\end{array}$ & 4 & 5 & 7 & 4 & 4 & 6 & 6 & 4 & 5 & 4 & 7 & 4 & 5 & 6 & 4 & 6 & 4 & 4 & 5 & 7 \\
\hline Job security & 2 & 1 & 1 & 1 & 1 & 1 & 1 & 1 & 1 & 1 & 3 & 1 & 1 & 2 & 1 & 1 & 1 & 1 & 1 & 1 \\
\hline $\begin{array}{l}\text { Promotion and } \\
\text { growth in } \\
\text { Organization }\end{array}$ & 8 & 6 & 4 & 7 & 6 & 4 & 8 & 6 & 6 & 5 & 8 & 7 & 4 & 5 & 2 & 2 & 8 & 3 & 7 & 8 \\
\hline $\begin{array}{l}\text { Good working } \\
\text { conditions }\end{array}$ & 7 & 4 & 3 & 6 & 5 & 3 & 5 & 5 & 4 & 3 & 6 & 5 & 3 & 7 & 3 & 3 & 6 & 5 & 4 & 6 \\
\hline $\begin{array}{l}\text { Personal loyalty } \\
\text { to employees }\end{array}$ & 3 & 3 & 5 & 3 & 3 & 5 & 2 & 3 & 3 & 2 & 1 & 2 & 7 & 3 & 8 & 4 & 2 & 7 & 2 & 2 \\
\hline $\begin{array}{l}\text { Sympathetic } \\
\text { help with } \\
\text { personal } \\
\text { problems }\end{array}$ & 5 & 7 & 6 & 5 & 8 & 7 & 4 & 8 & 7 & 6 & 2 & 6 & 8 & 4 & 6 & 1 & 5 & 8 & 6 & 4 \\
\hline
\end{tabular}

\section{References}

Afful-Broni, A. (2012). Relationship between Motivation and Job Performance at the University of Mines and Technology, Tarkwa, Ghana: Leadership Lessons. Creative Education, 3(3), 309-314. http://dx.doi.org/10.4236/ce.2012.33049

Chamorro-Premuzic, T. (2013). Does Money Really Affect Motivation? A review of the research. Harvard Business Review. Retrieved from http://blogs.hbr.org/2013/04/does-money-really-affect-motiv/

Ebong, A. P. (2007). Assessing the role of work Motivation on Employee Performance. Umeå School of Business and Economics. Retrieved from http://umu.diva-portal.org/smash/get/diva2:140549/FULLTEXT01.pdf

Goverrnment of the British Virgin Islands. (2014). Human Resources. Employee Motivation Survey. Retrieved from http://www.hr.gov.vg/upload/employee\%20motivation\%20survey.pdf

Judge, T., Piccolo, R., Podsakoff, N., Shaw, J., \& Rich, B. (2010). The relationship between pay and job satisfaction: A meta-analysis of the literature. Journal of Vocational Behavior, 77, 157-167. http://dx.doi.org/10.1016/j.jvb.2010.04.002

Kovach, K. (1987). What Motivates Employees? Workers and Supervisors Give Different Answers. Business Horizons, 58-65. http://dx.doi.org/10.1016/0007-6813(87)90082-6

Oleson, M. (2004). Exploring the relationship between money attitudes and Maslow's hierarchy of needs. $\begin{array}{lllll}\text { International Journal of Consumer } & \text { Studies, }\end{array}$ http://dx.doi.org/10.1111/j.1470-6431.2004.00338.x 
Vohs et al. (2006). The Psychological Consequences of Money. Science, 314, $1154-1156$. http://dx.doi.org/10.1126/science.1132491

William, A. (2010). Employee Motivation and Performance. Ultimate Companion Limited, Douala-Cameroon. Retrieved from http://www.theseus.fi/bitstream/handle/10024/22787/akah_william.pdf?sequence=1

\section{Copyrights}

Copyright for this article is retained by the author(s), with first publication rights granted to the journal.

This is an open-access article distributed under the terms and conditions of the Creative Commons Attribution license (http://creativecommons.org/licenses/by/3.0/). 